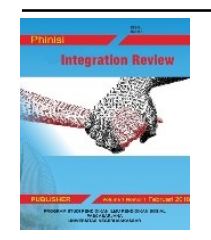

Phinisi Integration Review

Vol. 4, No.1, Februari 2021 Hal 64-72

Website: http://ojs.unm.ac.id/pir

p-ISSN: 2614-2325 dan e-ISSN: 2614-2317

DOI: https://doi.org/10.26858/pir.v4i1.19340

\title{
Formasi Sosial dan Keterpinggiran Dalam Pembangunan (Studi pada Pemulung dan Pengepul di Maros)
}

\author{
Dideng Kadir ${ }^{1}$, Adi Sumandiyar², Hasruddin Nur ${ }^{3}$ \\ Universitas Sawerigading Makassar, Indonesia \\ email: didengkadir6608@gmail.com
}

\begin{abstract}
Abstrak. Penelitian ini bertujuan menganalisis dan menjelaskan posisi kelompok pemulung dan peran pengepul dalam suatu formasi sosial dan keterpinggiran kelompok pemulung dalam pembangunan. Metode penelitian yang digunakan adalah jenis penelitian deskriptif kulitatif, dengan pendekatan fenomenologis. Hal ini dimaksudkan untuk dapat memberi deskripsi yang sistimatis, faktual, aktual terhadap objek yang diteliti. Penelitian ini berfokus, dan peranan pengepul dalam hubungan sosial kelompok pemulung di Maros yang menunjukkan adanya integrasi langsung maupun tidak langsung dengan kelompok masyarakat yang mendominasi pembangunan. Data dikumpulkan melalui wawancara mendalam, data dianalisis dengan beberapa langkah yaitu; (1) utilizing, (2) pengategorian, (3) interpretasi data. Kemudian data divalidasi oleh (1) perpanjangan waktu, (2) pengamatan, (3) tringulasi. Hasil penelitian menunjukkan, (1) pengepul berkontribusi terhadap pembangunan yaitu (a) mempekerjakan pemulung untuk memproduksi barang bekas, (b) pemulung berpatisipasi membersihkan lingkungan memungut sampah, (c) pengepul, industri berpatisipasi membayar pajak sebagai pendapatan negara, (2) keterpinggiran pemulungan disebabkan (a) pemulung masih tetap menggunakan moda produksi nonkapitalis, (b) tidak adanya keterlibatan langsung pemerintah terhadap pemulung dalam pembinaan dan kesejahteraan, (c) adanya tergantungan modal kepada pengepul, (d) tidak adanya lembaga sosial yang menggantikan pengepul sebagai pemberi modal.
\end{abstract}

Kata kunci: pemulung, pengepul, Bank industri, terpinggirkan.

\begin{abstract}
The objectives of this research are to analyze and explaining the position of group scavengers and the role of collection in social formation and marginalization in development. The researcher applied qualitative-descriptive method, using phenomelogy approach. The resulf of data analyze means giving sistimatic, factual, and actual describtion to the objrectives of this research focus on the role of collectors in the social relation with the group of scavengers showed by direct and indirect integration with the group who dominant in the development. Collection the data through close interview and then analyzing into several ways, they are; (1) utilizing, (2) categoring, (3) data interpretation. And then validating data with, (1) leng then time, (2) observation, (3) triangulation. The finding of the research are as follows; (1) the contribution of scavenger to the development are; (a) amploying the collector to collect the second-hand good, (b) collectors keep the environment clean by collecting the rubbish, (c) the industry and scavengers pay tax as national income, (2) the marginalization of collectors caused by; (a) collectors still using noncapitalism capital moda, (b) there is not direct involving of government in collectors safe and training, (c) there is dependend capital to the scavenger, (d) there is no sosial institution as the financial capital changed the scavenger.
\end{abstract}


Keywords: scavengers, collectors, Industry, bank marginalization.

Ini adalah artikel dengan akses terbuka dibawah licenci CC BY-NC-4.0

(https://creativecommons.org/licenses/by-nc/4.0/).

\section{PENDAHULUAN}

Formasi sosial adalah dua atau lebih moda produksi yakni moda produksi nonkapitalis dengan cara-cara tradisional, sementara moda produksi kapitalis dengan cara-cara serba modern, namun keduanya tidak hanya terkoeksistensi tetapi juga terhubungkan antara satu dengan lainnya, sekalipun dalam bentuk asimentris. Dalam formasi ini, termasuk moda produksi kapitalis pada umumnnya tampil sebagai moda produksi yang dominan sedangkan moda produksi lainnya berada pada posisi resisten (Arief, 2010)

Moda produksi adalah gabungan antara kekuatan produksi (forces of production) dengan hubungan produksi (relation of production). Hubungan produksi ini, merupakan faktor yang membedakan satu tipe produksi dengan tipe produksi lainnya. Salah satu contoh bentuk kegiatan yang dilakukan oleh masyarakat yaitu; (1) produksi subsisten misalnya, yaitu usaha pertanian tanaman pangan di mana hubungan produksi terbatas dalam keluarga inti dan hubungan antara pekerja bersifat egaliter, (2) produksi komersialis, yaitu usaha pertanian atau pun di luar pertanian yang sudah berorientasi pada pasar di mana hubungan produksi menunjuk padagejala eksploitasi surplus melalui ikatan egaliter, namun kompetitif, (3) produksi kapitalis, yaitu pada modal berorientasi pasar di mana hubungan produksi merupakan struktur buruh majikan atau tenaga kerja pemilik modal, (Sitorus, 1999, dalam Arif, 2010)

Menurut Suseno (1998) dalam pemikiran Marx berpendapat bahwa, moda produksi kapitalisme yang menyebabkan tereksploitasi tenaga kerja, karena upah yang diberikan oleh pemilik modal (pengepul) hanya upah semu saja, karena nilai lebih yang dihasilkan oleh barang industri tidak seimbang dengan pengorbanan yang dilakukan oleh buruh. Kapitalisme juga telah membelenggu kreatifitas buruh dari pekerjaan, karena adanya produksi mesin-mesin industry menjadikan buruh semakin tersisidan terjadi persaingan diantara mereka. Akibat dari semua ini, adalah ketidakberdayaan buruh untuk menolak upah rendah, yang ada hanya keterpaksaan bekerja dengan upah rendah dari pada harus tidak menerima upah sama sekali dan kehilangan pekerjaan.

Pengepul yang menguasai jasa pemulung, yang berusaha mencari pasar untuk memasarkan hasil produksi pulungan dari para pemulung, dan begitu pengepul mempunyai kemampuan membina hubungan kerja dengan lembaga-lembaga kapitalistik seperti bank, pabrik-pabrik atau industri, karena mereka memiliki pendidikan formal dan pengetahuan yang cukup untuk memperoleh modal dan pasar pada masyarakat kapitalis yang menggunakan modal produksi kapitalis dan mendominasi kelompok masyarakat yang hanya menggunakan moda produksi nonkapitalis, seperti kalangan kelompok pemulung dalam pembangunan. Masyarakat kapitalistik yang dominan dalam pembangunan telah melakukan kegiatan ekonomi yang ditujukan untuk kepentingan pasar menghasilkan laba dan memperoleh keuntungan modal yang lebih besar melalui berbagai macam penjualan kepada pihak industri. Karena masyarakat kapitalis dibangun di atas ekonomi pasar, sistem ekonomi yang dikontrol, diatur, dan diarahkan oleh pasar itu sendiri.

Menjadi pemulung merupakan pilihan alternatif yang terpaksa dipilih dan harus dilakukan, ini akibat dari ketimpangan pelaksanaan pembangunan dan ketidaksediaan atau ketidakmampuan pemerintah dalam menciptakan lapangan kerja, sehingga kelompok pemulung atau masyarakat marjinal dan terpinggirkan yang tidak dapat menikmati hasil pembangunan sekarang ini.

Terbatasnya penyedian lahan dipecahkan melalui kebijakan tata kota lahan dengan memanfaatkan daerah pinggiran sebagai pusat kota menjadi daerah yang padat penduduknya, yang dikondisikan searah dengan kemajuan pembangunan yang kebutuhan industri. Kebutuhan akan tenaga kerja dicukupi dengan perpindahan secara sukarela penduduk desa ke kota disebabkan daya tarik kota sebagai 
tempat memperbaiki nasib, akibatnya tidak terbendungnya proses migrasi sehingga tenaga kerja melimpah. Demikian juga dengan kebutuhan-kebutuhan lainnya, yang intinya lebih memusatkan perhatian dan kepentingan dari industrialisasi.

Di samping itu, konsekuensi dari pembangunan perkotaan yang konsisten dengan konsep pembangunan dan pertumbuhan ekonomi dan industrialisasi ini, juga menimbulkan terjadinya diskriminasi sikap perlakuan terhadap masyarakat. Utamanya masyarakat yang berada strata bawah, dengan asumsi akan menjadi beban dalam perhitungan peningkatan angka pertumbuhan pembangunan ekonomi. Seiring dengan kemajuan pembangunan, akan terciptanya kantong-kantong kemiskinan di daerah perkotaan, dengan ciri khas perkampungan kumuh, pemulung, organisasi kriminal, pelacuran, pedagang kaki lima, transfortasi informal, pendudukan tanah-tanah negara, yang pada intinya adalah hanya masyarakat terpinggirkan yang menempati posisi-posisi tersebut. Dan pada akhirnya masyarakat itu semakin terpinggirkan dan tersudutkan dalam kehidupan ditengah-tengah perkotaan,(Suparlan, 1986)

Hasil yang diperoleh dari observasi pada awal tahun 2013 yang telah dilakukan sebagai objek penelitian di Maros, maka diperoleh informasi berbagai sumber bahwa, dari beberapa tempat kerja ditemukan pada kelompok pemulung, dan ditemui 3 (tiga) kelompok besar pengepul yang memegang peranan penting dalam memainkankekuasaannyamempekerjakan tenaga kerja pemulung berjumlah puluhan orang yang tersebar berbagai tempat. Kelompok pemulung yang dimaksud adalah masyarakat terpinggirkan yang dikoordinir oleh pengepul atau dimanfaatkan mencari barang bekas sebagai sumber produksi bahan baku untuk kebutuhan industri. Di dalam pekerjaan ini yang menjadi ketertarikan orang bekerja pada sektor informal khususnya memulung barang bekas, karena mereka memperoleh sumber penghasilan untuk mencukupi kebutuhan keluarganya, dan mereka tidak mempunyai keterampilan, pendidikan yang cukup dan akses ke perolehan modal usaha.

Perekrutan tenaga pemulung sebagai sumber produksi barang bekas baik melalui pengepul maupun dari teman keteman yang didatangkan dari beberapa tempat dipulau jawa, seperti Jawa barat (Bandung), Jawa tengah dari Demak, Jawa timur, Cirebon, dan Solo.
Disamping itu, pengepul juga menyediakan fasilitas tempat tinggal dan pemberian modal awal, pinjaman modal kepada para pemulung dengan transaksi secara tradisional tanpa kuitansi, dan walaupun tanpa pernjanjian kerja yang dilakukan secara lisan, tapi atas dasar saling percaya. Akan tetapi keterikatan ketergantungan kedua belah pihak sebagai akibat terjadinya pemberian pinjaman atau modal utang piutang yang diberikan dari pihak pengepul.

\begin{tabular}{lrr}
\multicolumn{1}{c}{ Kehadiran pemulung } & sebagai \\
masyarakatterpinggirkan & & atau \\
termarjinalkansangat menjanjikan & bagi
\end{tabular}
sipengepul dan pemulung itu sendiri, dengan harapan mereka dapat hidup lebih baik untuk meningkatkan tarap hidup keluarga mereka. Namun pada kenyataannya, pemulung tidak dapat meningkatkan harapan kesejahteraan bagi keluarga mereka, dan tetap hidup dalam kemiskinan dan walaupun mereka mampu bertahan dalam kehidupan dengan kondisi sangat memperhatinkan. Hal ini disebabkan karena, para pemulung tidak mempunyai pekerjaan lain, dan keterampilan yang mereka miliki, sehingga hidup mereka sangat tergantung pada pengepul, apalagi di Maros mereka hidup hanya sebagai perantau yang tidak memiliki banyak pilihan pekerjaan.

Hubungan pengepul dengan pemulung terjalin dan terbangun dalam bentuk patron-klien, pemulung diharapkan bekerja keras untuk memberikan pendapatan yang optimal bagi pengepul. Situasi seperti ini, tentunya kurang menguntungkan bagi pemulung dan kadangkadang menimbulkan antipati pula pengepul, dan pemulung menganggap mereka sebagai pihak yang dieksploitasi, dan mereka dibuat ketidakberdayaan melakukan perlawanan hanya mengikuti apa keinginan pengepul saja. Dalam Undang-undang Nomor, 23 tahun 2002, mengenai perlindungan anak adalah anak orang tua atau pihak lain, yaitu menempatkan, membiarkan, melakukan menyuruh atau turut serta melakukan eksploitasi ekonomi atau seksual terhadap anak. Sehingga eksploitasi anak adalah tindakan tidak terpuji, karena tindakan eksploitasi anak telah merampas hakhak, misalnya mendapatkan kasih sayang dari orang tua, pendidikan yang layak, dan sarana bermain sesuai dengan usianya. Selanjutnya, Scott (Gafur, 2009) eksploitasi adalah suatu tata hubungan yang menunjukkan unsur-unsur ketidaksamaan dan paksaan yang begitu dominan dibandingkan dengan tata hubungan 
lainnya, sehingga tata hubungan ini dapat dengan mudah dikenali ciri yang lebih bersifat eksploitasi jika dilihat dari prespektif yang objektif. Pada gilirannya, kepentingan pengepul sangat bertentangan dengan kepentingan para pemulung yang hanya berkepentingan untuk meningkatnya pendapatan dan kesejahteraan mereka sendiri. Lebih lanjut, menurut Joni (2006) mengatakan bahwa, eksploitasi adalah suatu tindakan memperalat individu lain untuk tujuan kepentingan diri sendiri.

Oleh karena itu, biasaanya atau pada umumnya pemulung memiliki keinginan untuk berhenti bekerja pada seorang pengepul untuk bekerja sendiri secara bebas, namun dibalik itu tidaklah mudah dilakukannya. Walau pun ada beberapa orang diantara mereka melepaskan dirinya dari pengepul tertentu dan pindah pada pengepul lainnya. Sementara lainya tidak mampu melepaskan dirinya, karena tidak mempunyai pilihan lain. Karenanya disamping itu pula, adanya perilaku-perilaku pengepul (patron), di mana hasil pulungan yang telah diperoleh atau dikumpulkan dipotong 10 (sepuluh) persen dari hasil pulungan mereka misalnya hanya karena, dengan alasan barang bekas atau hasil pulungan itu basah. Namun para pemulung tidak dapat berbuat apa pun dan mereka menerima suatu kenyataan dari perlakuan pengepul itu sendiri, karena mereka tidak mempuyai kemampuan melawan, dikarenakan tekanan oleh utang-utang mereka dari pengepul. Ini membuat mereka semakin terbelenggu dan sangat sulit melepaskan diri dari dominasi pengepul (patron). Di sisi lain pula, kelompok pemulung yang dikategorikan menggunakan moda produksi non-kapitalis atau dengan perkataan lain, sumber produksi mereka hanya difungsikan sebagai penerima harga (price taker). Sementara pengepul akan bertindak sebagai price makers yang lebih dominan menguasai pasar. Mereka akan mengambil keputusan-keputusan yang menguntungkan dirinya dan memaksimumkan keuntungan mereka. Keputusan pengepul cenderung diambil secara sepihak, tanpa mempertimbangkan kepentingan pihak yang dikuasainya. Di lain pihak, pemulung sebagai price taker hanya pengikut pasar dan secara individu mereka tidak mampu dan tidak memiliki tawar menawar (bargaining) dalam menentukan harga mau pun keputusankeputusan dasar di pasar yang bisa membuka peluang untuk meraih keuntungan bagi mereka. Dalam kondisi seperti ini, cukup kuat diduga bahwa, para pemulung merasa tereksploitasi dan semakin terpinggirkan dalam kehidupan yang dapat menimbulkan dari ketidaknyamanan melakukan pekerjaan, walau pun tidak memperlihatkan wajah atau suatu aksi melawan, akan tetapi hati mereka tidak nyaman. Hal ini, dapat dirasakan ketika harga dan kesenjangan pendapatan semakin tajam perbedaan antara pengepul. Pengepul dapat memainkan harga yang sesukanya. Sementara pemulung semakin dijauhkan dari tidak tahu menahu tentang naik atau turunnya harga produksi pulungan di pasar, karena mereka tidak memiliki akses untuk berghubungan langsung dengan industry untuk pemasaran hasil produksi tersebut.

Untuk lebih mengetahui realitas sosial sebagaimana yang diungkapkan pada latar belakang di atas, dikenal dua konsep penting yakni formasi sosial dan moda produksi.

Formasi sosial terbentuk oleh adanya dua moda produksi yakni moda produksi nonkapitalis dan moda produksi kapitalis, di mana salah satunya tampil mendominasi yang lainnya. Moda produksi merupakan gabungan antara kekuatan produksi dan hubungan produksi. Pada kelompok masyarakat terpinggirkan yang menggunakan moda produksi non-kapitalis yang subsisten, mereka berkoeksistensi dengan masyarakat pembangunan yang kapitalistik tetapi cenderung tidak terhubungkan antara satu dengan yang lainnya. Ini berbeda dengan kelompok pemulung yang berada dalam lingkup produksi yang non-subsisten. Seperti halnya antara kelompok pemulung dengan kelompok masyarakat yang dominan dalam pembangunan, walaupun mereka juga menggunakan moda produksi yang non-kapitalistik, namun mereka tidak hanya berkoeksistensi, tetapi juga terhubungkan dengan masyarakat yang mendominasi pembangunan. Dengan perkataan lain, mereka terhubungkan dengan mata rantai pembangunan.

Namun dalam hubungan itu, situasi
pertukaran yang terjadi cenderung mempertahankan situasi pertukaran yang timpang, di mana kelompok yang mendominasi pembangunan memperoleh kemajuan yang lebih besar, bahkan jauh labih baik dari pada yang diperoleh kelompok pemulung. Oleh karena itu, dalam fokus penelitian ini adalah, (1) Formasi sosial berkontribusi terhadap pembangunan, (2) Formasi sosial menyebabkan salah satu entitas yakni kelompok pemulung terpinggirkan atau termarjinalkan dalam kehidupan mereka.

\section{METODE}


Kadir, Sumandiyar, Nur. Formasi Sosial dan Keterpinggiran Dalam Pembangunan...

Jenis Penelitian ini menggunakan pendekatan penelitian kualitatif. Menurut meleong (2010) mengatakan bahwa, pendekatan kualitatif menghasilkan data dekskriptif kualitatif berupa informasi lisan dan tulisan dari berbagai subjek yang diteliti, serta tingkah laku mereka yang dapat diamati secara holistik.

Penelitian ini bertujuan untuk memahami dalam pengolahan data, tentang formasi sosial berkontribusi dalam pembangunan dan kelompok pemulung termarjinalkan dalam pembangunan yang berlokasi penelitian di Kabupaten Maros. Yang menjadi instrumen utama (key instrument) dalam penelitian ini adalah peneliti sendiri menggunakan alat bantu berupa pedoman wawancara, dokumen dan catatan lapangan. Informan ditentukan secara purposive sampling, dan juga menggunakan sumber data primer dan data sekunder, teknik pengumpulan data,yaitu observasi, wawancara, dokumentasi, kemudian dianalisis melalui tahapan penegempulan data (dataCollection) mereduksi data (data reduction), penyajian data (display data), penarikan kesimpulan (Verificatin), kemudian menggunakan teknik keabsahan data yaitu tringulasi sumber, teringulasi teknik dan tringulasi waktu.

\section{HASIL DAN PEMBAHASAN}

\section{Kontribusi Formasi Sosial dalam Pembangunan.}

\section{Berpartisifasi menciptakan lapangan} kerja.

Kebutuhan lapangan pekerjaan merupakan kebutuhan setiap manusia. Pengepul salah satu pengusaha kecil yang mampu mempekerjakan banyak orang tenaga pemulung, walaupun prekrutannya tenaga tersebut tidak memerlukan pendidikan, keterampilan khusus yang penting mereka mempunyai komitmen untuk bekerja dan jujur. Aktifitas pemulung sehari-harinya mencari barang bekas untuk keperluan pengepul sekaligus bahan baku untuk industri. Sementara pihak industri yang bergerak disektor formal yang juga lebih banyak menyerap tenaga kerja professional di mana perekrutan tenaga kerja lebih selektif melalui tes dan wawancara. Peluang pekerjaan ini dapat memberikan kesejahteraan untuk keluarganya.

Keberadaan pengepul disektor informal sangat membantu pemerintah dalam penyediaan lapangan kerja sebagai tanggung jawab warga negara, di mana pemerintah sampai sekarang ini belum mampu menyerap tenaga kerja secara keseluruhan, sehingga terjadi banyak pengangguran. Pengangguran merupakan masalah besar yang tidak kunjung mendapatkan solusi. Ketidaktersediaan lapangan kerja merupakan identik munculnya masyarakat miskin. Karena pilihan memulung merupakan alternatif dari krisis pekerjaan. Walaupun pekerja pemulung tidak ada yang parmanen yang sifat kontemporer, tergantung kepada pemulung itu sendiri, mana kala pemulung sudah mau berhenti bekerja pada pengepul, maka pengepul tidak akan mengahalanginya karena tidak ikatan kontrak yang mengikatnya, sepanjang pemulung tidak mempunyai utang atau sudah tidak sanggup lagi bekerja.

Sebagaimana dikatakan seorang pengepul menjelaskan bahwa Jika dilihat usaha saya ini, boleh dikatakan tidak berarti bagi masyarakat tertentu atau kalangan masyarakat atas, karena usaha saya ini bergerak dibidang barang rongsokan, kotor, menjijikkan yang masih tidak banyak orang tertarik di usaha ini. namun usaha saya ini menjadi pilihan alternatif masyarakat sebagai peluang lapangan kerja. Lapangan kerja di sektor formal sangat susah, karena pemerintah tidak mampu menyediakan lapangan kerja tersebut. Justru usaha saya ini menganggap penting dalam membantu pemerintah untuk menanggulangi pengangguran di masyarakat. (Hasil wawancara, tanggal 13 November 2013).

Pengepul salah satu entitas dari formasi sosial yang merasa rasa mempunyai tanggung jawab bahwa, perusahaan mereka dapat membuka lapangan kerja dan memberikan peluang bagi masyarakat pemulung ataupun masyarakat luas yang tertarik dalam pekerjaan ini untuk memperoleh penghasilan dan biaya keluarganya walaupun masih jauh dari harapan penghasilan yang memadai. Kesempatan kerja bagi seseorang untuk memenuhi kebutuhan keluarga mereka. Pengepul di daerah ini, banyak tersebar berbagai tempat dan dapat menampung tenaga kerja pemulung yang cukup banyak untuk membantu beban pemerintah sebagai penyediaan lapangan kerja. oleh karena, kebijaksanaan negara dalam kesempatan kerja meliputi upaya-upaya untuk mendorong pertumbuhan dan perluasan lapangan kerja di setiap daerah, serta perkembangan jumlah dan kualitas lapangan kerja yang tersedia, agar dapat memanfaatkan seluruh potensi masyarakat yang ada di daerah masing-masing. Oleh karenapengepul merasa bertanggung jawab sebagai warga negara dalam penanggulangan atau mengatasi membludaknya pengangguran 
yang pada akhirnya menimbulkan kemiskinan. Karena pengangguran merupakan problematika kehidupan sosial yang harus ditanggulangi oleh pemerintah. Tingginya pengangguran akan semakin tingginya tingkat kemiskinan. Sebaliknya jika tersedianya lapangan kerja akan dapat mengurangi kemiskinan dan memberikan kesejahteraan masyarakat. Selanjutnya Mustakir mengatakan bahwa, Usaha saya ini dapat memberikan peluang bagi masyarakat untuk memperoleh lapangan kerja, khususnya menampung tenaga kerja pemulung. Karena saya menyadari betapa susahnya pekerjaan sekarang ini, sehingga saya merasa bertanggung jawab sebagai warga negara dapat menyediakan lapangan kerja untuk menanggulangi penggangguran di masyarakat. Namun tidak semua orang tertarik bekerja seperti ini, bukan saja penyediaan lapangan kerja, tetapi sering pula berpatisipasi dalam kegiatan lainnya di masyarakat, (Hasil wawancara tanggal 26 November 2013).

\section{Berpartisipasi membayar pajak}

Sebagai warga negara berkewajiban membayar pajak baik secara individu maupun perusahaan yang berskala besar yang mempunyai tanggung jawab membiayai pembangunan. Orang yang mempunyai penghasilan besar pasti pajaknya besar, yang kecil, bayar pajaknya juga kecil. Pengepul salah satu pengusaha kecil dan bagian dari masyarakat luas yang mempunyai tanggungjawab membangun melalui pembayaran pajak. Pajak adalah salah satu kontribusi pendapatan negara untuk membiayai pembangunan. Kemajuan pembangunan Di sini bisa diambil hikmah bahwa kita belajar saling mengisi atau disebut subsidi silang. Maka dilihat dari sudut pandang pemanfaatan pajak untuk kepentingan umum yang sudah sewajarnya pajak menjadi kewajiban atau hukumnya wajib bagi masyarakat sesuai wajib pajak yang dibebankan oleh negara.

Lebih lanjut Tohir salah satu pengepul mengemukakan, selain perusahaan secara resmi mempunyai izin dari pemerintah dan perusahaan dan setiap tahunnya membayar pajak. Karena sebagai pengusaha berkewajiban membayar pajak sebagai bentuk tanggung jawab dalam membiayai pembangunan yang kita rasakan sekarang ini, (wawancara, tanggal

November 2014).

\section{Kontribusi Terhadap Pembangunan Lingkungan.}

Pemulung salah satu bagian dari masyarakat berperan serta di dalam membantu pemerintah untuk memelihara lingkungan. Lingkungan yang bersih merupakan kebutuhan setiap manusia. Pemeliharaan lingkungan bukan saja tanggung jawab dari pemerintah daerah, melainkan tanggung jawab bersama masyarakat yang bermukin di daerah tersebut. Keberadaan kelompok pemulung salah satu bentuk bagian kecil untuk membantu pemerintah daerah berpatisipasi memelihara lingkungan seperti memungut sampah atau barang bekas di jalan, di tempat-tempat sampah ataupun di acara-acara pesta perkawinan.

Pekerjaan pemulung menyadari, bahwa barang bekas dapat bernilai uang yang dapat meningkatkan ekonomi masyarakat. Disamping itu turut membantu membersihkan lingkungan. Sampah bukan saja dibuang ditempat sampah berupa gelas plastik dan sejenisnya, melainkan juga banyak membuang begitu saja yang dapat menggangu kebersihan lingungan melalui acara-acara perkawinan, ulang tahun, yang kadang-kadang tidak sempat dibersihkan. Pemulung salah satu peranya memanfaatkannya, selain bernilai ekonomi untuk menghasilkan uang, juga turut baik langsung maupun tidak langsung untuk membersihkan dan memelihara lingkungan tersebut.

\section{Formasi Sosia Menyebabkan Kelompok Pemulung Terpinggirkan atau Termarjinalkan.}

Keterpinggiran atau termarjinalkan pemulung bukan saja satu-satunya penyebab dari entitas pengepul, akan tetapi sesungguhnya juga disebabkan suatu kondisi sosial ekonomi yang dialami yang membuat suatu keadaan kelompok pemulung terpinggirkan. Karena pada masyarakat kelompok pemulung itu sendiri yang masih tetap menggunakan moda produksi nonkapitalis, sebagai konsekuensi ketidakmampuan mengakses moda produksi kapitalis, seperti halnya tidak mempunyai pendidikan, keterampilan dan modal, sehingga ketergantungan secara terus menerus, antara lain, dikarenakan semua hasil produksi pemulung dijual melalui pengepul itu sendiri (Hartanto,2011)

Kemajuan pembangunan pun juga salah satu faktor yang mempengaruhi suatu keadaan dan kondisi ekonomi pemulung yang tidak mampu bersaing secara global. Di mana posisi pemulung ditempatkan tidak menguntungkan, sebaliknya pada posisi pengepul yang 
mempunyai kekuasaan lebih luas berada pada posisi menguntungkan yang memainkan peran memanfaatkan situasi ekonomi melalu perusahaan mereka. Pembangunan ekonomi akan berdampak positif dan berpihak kepada masyarakat kelompok pemulung atau termarjinalkan untuk menikmati kesejahteraan pembangunan. Akan tetapi sebaliknya, jika pembangunan ekonomi tidak mampu memberikan kesejahteraan masyarakat pada umumnya dan khususnya kelompok pemulung, maka kelompok tersebut semakin termarjinalkan dalam kehidupan ditengah-tengah masyarakat luas.

Seharusnya pemerintah daerah setempat masyarakat miskin mendapat perhatian khusus untuk menikmati hasil pembangunan, namun pada kenyataannya bahwa, pemerintah daerah tidak mampu mengentaskan kemiskinan. Dengan kata lain, mereka pemulunglah yang salah satunya dari kelompok masyarakat terpinggirkan atau termarjinalkan. Seiring dengan kemajuan pembangunan ekonomi dalam rangka meningkatkan kesejateraan masyarakat miskin, yang seharusnya masyarakat kapitalis mengangkat dan martabat miskin untuk mensejahterakan.

Edy widodo (43) mengatakan bahwa, saya adalah orang masyarakat miskin, pekerjaan memulung seperti ini, kondisi ekonomi yang saya alami sangat memprihatinkan dan sebenarnya keterpaksaan menerima keadaan ini, sampai sekarang ini belum mampu memperbaiki kehidupan saya sebagaimana layaknya orang lain. Disamping itu biaya hidup semakin tinggi, harga melambung, pendapatan tidak meningkat. Demikian pula harga hasil pulungan dari pengepul tidak menentu tergantung dari keinginan harga yang ditentukan, karena naik turunnya harga saya tidak tahu berapa perkilonya.Pinjaman modal nampaknya susah untuk melunasi kepada pihak pengepul, (wawancara tanggal 10 Juni 2014)

Jika dilihat dari fenomena kehidupan pemulung sangatlah memprihatikan yang dialaminya. Salah satu pengaruhnya dari pengepul adalah memperlakukan harga yang tidak terjadi tawar menawar kepada pemulung, sehingga sangat sulit diprediksi berapa pendapatan setiap harinya. Di sisi lain juga keadaan ekonomi tidak menentu membuat mereka tidak mampu bersaing uuntuk memenuhi kebutuhan sehari-hari. Selanjutnya, kondisi ekonomi para pemulung semakin jauh dari harapan dan kesejahteraan yang memadai, semakin tersisihkan atau terpinggirkan dari kehidupan yang layak. Sesungguhnya pembangunan yang diyakini bakal mampu mewujudkan kesejahteraan rakyat, ternyata di beberapa daerah khususnya di Maros belum dapat terbuktikan keberhasilan pembangunan kesejahteraan masyarakat pada umumnya. Perbaikan pendapatan masyarakat sangat ditentukan peran pemerintah daerah setempat atau para pemilk modal yang dapat membantu pada masyarakat yang membuthkan. Salah satunya yang bisa dilakukaan adalah perluasan kesempatan kerja sehingga masyarakat dapat meningkatkan taraf hidupnya.

Sebagaimana di katakan Nasuha (42) salah seorang pemulung, mengatakan bahwa, selama saya menjadi pemulung kurang lebih 5 tahun di daerah ini, kehidupan saya tetap seperti begini, walau pun lebih baik jika dibandingkan dikampung. Namun perasaan saya selalu gelisah ingin memperoleh keinginan kehidupan lebih baik, perbaikan pendapatan dari hasil pekerjaan ini, terutama dari segi harga yang sama sekali tidak tahu harga sesungguhnya, apalagi tidak pernah tawar menawar harga. Karena ketika saya pulang dari pekerjaan, hasil pulungan langsung ditimbang oleh pengepul dan membayar harga sesuai dengan harga yang ditetapkan pengepul sendiri, sehingga sangat sulit untuk memperbaiki keadaan ekonomi saya, hanya cukup untuk dimakan saja bayar utang. Hal ini disebabkan karena ketergantungan modal dari mereka, dan sulit melepaskan diri, karena utang tidak pernah habis, (Wawancara, tanggal 16 Juni 2014)

Bila dicermati dari hasil wawancara informan bahwa, sesungguhnya formasi sosial meminggirkan kelompok pemulung, karena mereka tidak bisa mengakses ke industri kapitalis tanpa melalui perantara pengepul. Ketidak mampuan mengakses ke pihak industri atau perbankan, karena produksi pemulung adalah bertentangan dengan moda produksi kapitalis yang digunakan oleh industri/perbankan atau kapitalis. Sebagai akaibat adanya atrikulasi dua moda produksi tersebut dimanfaatkan oleh pengepul sebagai mediasi, karena pengepul mampu menggunakan dua moda produksi sekaligus. Ketika ia berhubungan dengan pemulung ia menggunakan moda produksi nokapitalis, sebaliknya, ketika berhubungan dengan pihak industri/perbankan menggunakan moda produksi kapitalis dan dalam perananya sebagai sebagai mediator tersebut, pengepul memiliki tawar menawar 
(bargaining power) yang menyebabkan kelompok pemulung tidak mampu melepaskan diri dari ketergantungan dengan kondisi ekonomi yang memprihatinkan.

Ketergantungan modal pemulung kepada pengepul menjadi faktor utama ketidakberdayaan membuat mereka tidak bisa memperbaiki kondisi yang dialaminya, karena pemulung tidak mampu melakukan tawar menawar (bargaining power) harga kepada pengepul, sehingga apapun keputusan pengepul memberi dengan harga murah harus diterima. Jika dilihat norma-norma dan hak asasi manusia, sesungguhnya masyarakat pemulung ingin merasakan hidupsejahtera menikmati hasil pekerjaannya. Tetapi kesenjangan dalam kesejahteraan ekonomi, pengepul tidak menjadi pertimbangan untuk menerima permintaan tawar menawar harga pulungan dari pemulung, sehingga kehidupan sebagai masyarakat miskin seolah-olah terabaikan, namun tidak berati serta merta pengepul secara keseluruhan memperlakukan pemulung sesuai dengan kehendaknya saja.

\section{SIMPULAN DAN SARAN}

Berdasarkan uraian tersebut diatas, maka disimpulkan sebagai berikut: Hasil penelitian menunjukkan, (1) Pengepul berkontribusi terhadap pembangunan yaitu (a) mempekerjakan pemulung untuk memproduksi atau memperoleh barang bekas,

pemulung berkontribusi dan berpatisipasi membersihkan lingkungan memungut sampah, (c) pengepul mempunyai peranan penting terhadap industri perusahan yang dia miliki dan berpatisipasi membayar pajak secara rutin setiap tahun yang merupakan tanggung jawab sebagai komponen masyarakat sebagai sumber pendapatan negara,(2) keterpinggiran pemulung disebabkan (a) Pemulung masih tetap menggunakan moda produksi nonkapitalis sehingga entitas ini, tidak memiliki akses untuk memasarkan hasil produksi pulungan langsung ke pihak industri, demikian pula karena mereka juga tidak memiliki akses untuk perolehan modal bagi kegiatan kerja mereka (b) tidak adanya keterlibatan langsung pemerintah terhadap pemulung dalam pembinaan dan kesejahteraan untuk memperoleh modal dan pemasaran hasil pulungan langsung ke industri (c) adanya tergantungan modal dari secara terus menerus menyebabkan pemulung tidak memiliki kekuatan tawar menawar (bargaining pawer) terhadap pihak pengepul, (d) tidak adanya lembaga sosial lain yang dapat menggantikan posisi pengepul sebagai pemberi modal kerja pemulung dan memasarkan hasil pulungan mereka.

Berdasarkan hasil penelitian ini, dapat dilihat dari kelompok pemulung yang menggunakan moda produksi non-kapitalis, sementara pengepul yang menggunakan moda produksi kapitalis, maka dapat diajukan beberapa saran sebagai berikut:(1) Diperlukan keterlibatan pemerintah dalam pengambilan kebijakan untuk mengangkat harkat dan martabat pemulung sebagai masyarakat tertindas. Karena pemulung mempunyai potensi dalam pengembangan perekonomian untuk memenuhi kebutuhan mereka. Akan tetapi pemulung tidak mendapatkan pembinaan dan sosialisasi yang memungkinkan mereka beradaptasi dan mampu mengakses lembagalembaga yang mendominasi pembangunan yakni industi dan perbankan, (2)Kelompok pemulung sebagai masyarakat terpinggirkan atau termarjinalkan dalam suatu kondisi formasi sosial yang terbentuk diperlukan adanya intervensi dalam hal memfasilitasi sebuah organisasi, atau lembaga, misalnya koperasi simpan pinjam, di mana lembaga tersebut, berperan memediasi kepentingan kelompok pemulung dengan dunia industri/perbankan tanpa merugikan kelompok pemulung, (3) Keterlibatan pemerintah daerah diperlukan adanya pembinaan pelatihan, dan keterampilan pemulung agar mereka dapat hidup layak, mandiri dan lepas dari belenggu ketergantungan modal pengepul, (4)Kelompok pemulung sebagai masyarakat terpinggirkan atau termarjinalkan dalam suatu kondisi ekonomi, tentunya diperlukan adanya intervensi pemerintah dalam hal memfasilitasi sebuah organisasi koperasi untuk menggantikan peran pengepul sebagai pemilik modal, agar kelompok pemulung dapat terhindar dari eksploitasi.

\section{DAFTAR RUJUKAN}

Arief, Adri. 2010. Studi Pustaka Formasi Sosial dan Atikulasi ModernisasiPerikanan, Makassar, Universitas Hasanuddin.

Gafur, 2010. Manusia Gerobak: Kajian Mengenai Taktik-taktik Pemulung Jatinegara di Tengah Kemiskinan Kota. Lembaga Penelitian SMERU. 
Kadir, Sumandiyar, Nur. Formasi Sosial dan Keterpinggiran Dalam Pembangunan...

Research Institute. Menuju Undang-undang Nomor: 23 Tahun 2002.

kebijakan promasyarakat miskin.

Hartanto,2011.SiapaKelompokMarjinal.http://si Pengertian eksploitasi:www.wikipedia. nduhartanto.wordpress.com.Diakse Diakses tanggal 25 Agustus 2013. s tanggal 2 September 2013.

Joni, 2002. Pengertian eksploitasi. Maxmanroe. Diakses tanggal 14 September 2013

Karl

Marx,

Marxismehttp://rioapinino.blogspot com $/ 2011 / 10 /$ karl-marx-teori-

kelas.html. diakses tanggal, 14 Oktober 2014

Moleong, J.L, 2010. Metode Penelitian KualitatifEdisi Revisi. Bandung: PT. Remaja Rosdakarya.

Purnomo, M. 2005. Perubahan Struktur Ekonomi Lokal: Studi Dinamika Moda Produksi di Desa Pegunungan Jawa. Tesis: Pascasarjana Institut Pertanian Bogor.

Sitorus, 1999. Pembentukan Golongan Pengusaha Lokal di Indonesia: Pengusaha Tenun Bandung: Humaniora Utama Press.

Suparlan, Persudi, 1986. Sebuah Konsekuensi Perkembangan Kotadalam Gelandangan Pandangan Ilmu Sosial. Jakarta: LP3ES.

Suseno, F. 1998. Pemikiran Karl Marx. Dari Sosialisme utopis kePerselisihan Revisionisme. Jakarta: Gramedia. http://www.scribd.com/doc/542763 49/8/ Struktur- ketergantungan dan moda produksi. Diakses tanggal 17 Juli 2013.

Scott, J. C. 1972. Patron Client Politics and Change In South East Asia (dalam Friends, Follwers and Factions, A Reader In Political Clieantalism) diedit oleh Steffen W Schmidt, et.al. Berkeley Los Angeles, London: University of California Press. 